\title{
PROJECT PROFITABILITY ANALYSIS
}

\author{
Aleksandar Ž. Drenovac ${ }^{a}, B_{\text {Batislav Ž. Drenovac }}{ }^{b}$ \\ a Drenus, Belgrade, Republic of Serbia, \\ e-mail: aleksandar.drenovac@yahoo.com, \\ ORCID iD: (Dhttp://orcid.org/0000-0003-2775-397X \\ b Serbian Armed Forces, Center for Training and Development, \\ Training Command, Belgrade, Republic of Serbia, \\ e-mail: drenovac.b@gmail.com, \\ ORCID iD: (Dhttp://orcid.org/0000-0001-5851-3915
}

http://dx.doi.org/10.5937/vojtehg66-6363

FIELD: Project Management, Portfolio Management, Investment Analysis ARTICLE TYPE: Professional Paper ARTICLE LANGUAGE: English

\section{Summary:}

Numerous activities in modern business are performed through projects. Since projects are often very expensive, long-lasting, ans involve large amounts of assets and people for completing them, a decision about starting a project is to be based on measurable parameters.

Key words: project management, project budget, investment analysis.

\section{Introduction}

Project management is becoming more and more important, and in some areas a dominant way of realizing plans and activities. Through the change of the concept of realization of planned and agreed jobs, there is also a need to change the form of organization, that is, to switch from a functional type to a project type of organization.

As a transition state, a large number of organizations establish matrix organizations, where the functional structure is retained, and project teams engaged during the duration of a specific project stand out as a special element. However, project-organized companies show the highest efficiency and effectiveness, with the most flexible market access, precisely because of the ability to react very quickly to market demands and adapt to the needs and demands of the market and users.

The reasons for launching projects can be very different, but it is certainly a common line of all projects to run for the purpose of satisfying a 
specific need or problem solving (Project Management Institute, 2013, p.3). In this sense, projects must satisfy several conditions and requirements, which are declared together as a group of SMART requirements (S-Specific, M-Measurable, A-Adequate, Ambitious, Achievable, R-Realistic, T-Time based) - they must be in every way worthwhile.

Therefore, their activities must be useful, and in any way justify the launch and realization of the project, i.e. all the engaged resources and investments (Đedović, pp.25-29).

The investment analysis is one of the most important factors in deciding to initiate a project, but also in selecting a particular project among several different ones.

\section{Projection of the project budget}

The basic characteristic of each project is a triple limit, expressed through the scope (area) of the project, time (duration) and budget (costs), so that each of these items affects significantly the quality.

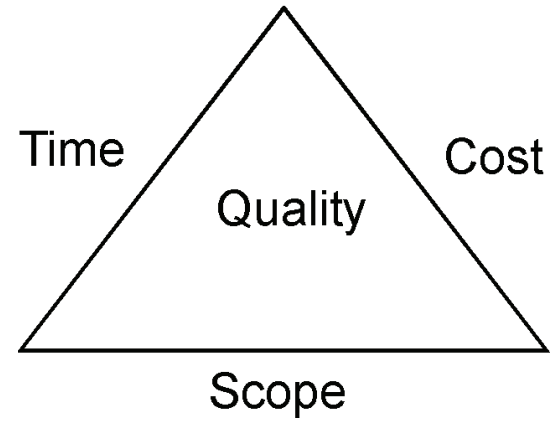

Figure 1 - Triple project constraint

Puс. 1 - Тройное ограничение проекта

Слика 1 - Троструко ограничење пројекта

Changing each item will have a significant impact on quality, with simultaneous change and other parameters, in all stages and on the complete project. As the scope, time and quality are factors of a different character, the budget often appears as a decisive factor in the planning and implementation of the project (Barkley \& Saylor, p.83).

A particular problem in the realization of each project, but also in the budget planning is one of the key characteristics of the project - that each project is a unique venture, whose results are always unique products and 
services, and which is realized in a unique way, in unique conditions, with unique resources, etc.

For long, costly and complex projects, it is not always easy to estimate the project budget, especially if the market conditions are not stable (Khoury, pp.1-3). Nevertheless, it is certainly a good parametric assessment, based on real market data on the price of products and services needed for the realization of the activities, every phase or project as a whole.

Also, an expert assessment can be very reliable, based on an expert's assessment for specific areas.

An experienced assessment also provides great reliability, and is based on experiential data from the realization of previous, similar projects.

\section{Quantitative analysis}

The cost-effectiveness of the project can be seen from many angles, depending on the nature of the project, but also on the indirect impacts on the development of a particular area or from the indirect revenues that result from the project.

The quantitative analysis is one of the basic elements in deciding to start a project, but also to analyze the justification of choosing one out of several offered projects. It is based on expected (estimated, planned) investments - expenditures, and estimated revenues in a given period (DeCarlo, p.332).

The return on investment for certain projects may be after a very long period, depending on the nature of the project and the area in which it is being implemented.

Regardless of the nature of the project, each investor will be of great importance for the return on the investment rate, the return period of investments, the net present value of the realized profit, and the rate at which returns would be returned.

Different questions and dilemmas can be posed for certain cases: how long will be the return of the investment return, or when the net balance, i.e. the total amount of cash flows, will arise; when profits will start to appear; whether the return on investment is greater than the interest rate that we could achieve in the banking or investment sector.

A characteristic case is projects that are not directly profitable, but they represent the entrance to subsequent projects. In this case, the costeffectiveness of the project will not be measurable through investment parameters, nor in the case when the completion of the project is realized 
as one-time income, i.e. the entire sales project without the realization of cumulative revenues in the following period.

In the case of a single project, planned investments and revenues would be distributed by periods and items, so that during the planning and realization of the project only costs occur, and since the activation of the project, revenues are generated, with the necessary further investments (Gitman, pp.321-337).

Table 1 - Project outcomes

Таблица 1 - Расходы проекта

Табела 1 - Расходи пројекта

\begin{tabular}{|l|l|l|l|l|l|l|}
\hline Investments & Initial & Year 1 & Year 2 & Year 3 & Year 4 & Year 5 \\
\hline Equipment purchase & $600 €$ & $/$ & $/$ & $400 €$ & $/$ & $/$ \\
\hline Renting an object & $3000 €$ & $3000 €$ & $3000 €$ & $3000 €$ & $3000 €$ & $3000 €$ \\
\hline Certification & $1200 €$ & $/$ & $/$ & $1000 €$ & $/$ & $/$ \\
\hline Procurement of software & $4000 €$ & $2000 €$ & $/$ & $/$ & $/$ & $/$ \\
\hline Salaries & $3000 €$ & $3500 €$ & $4000 €$ & $4500 €$ & $5000 €$ & $5500 €$ \\
\hline Travelling & $1200 €$ & $2000 €$ & $2200 €$ & $2400 €$ & $2400 €$ & $2400 €$ \\
\hline Ongoing costs & $2000 €$ & $2200 €$ & $2200 €$ & $2200 €$ & $2200 €$ & $2200 €$ \\
\hline
\end{tabular}

Table 2 - Project incomes

Таблица 2 - Доходы проекта

Табела 2 - Приходи пројекта

\begin{tabular}{|l|l|l|l|l|l|l|}
\hline Incomes & Initial & Year 1 & Year 2 & Year 3 & Year 4 & Year 5 \\
\hline Consulting & $/$ & $4000 €$ & $6000 €$ & $6000 €$ & $6000 €$ & $6000 €$ \\
\hline Software implementation & $/$ & $2000 €$ & $2500 €$ & $3000 €$ & $3500 €$ & $4000 €$ \\
\hline Business education & $/$ & $4000 €$ & $4000 €$ & $5000 €$ & $6000 €$ & $6000 €$ \\
\hline Realization of projects & $/$ & $2800 €$ & $3200 €$ & $3500 €$ & $4000 €$ & $4500 €$ \\
\hline
\end{tabular}

Table 3-Project incomes

Таблица 3 - Доходы проекта

Табела 3 - Приходи пројекта

\begin{tabular}{|l|l|l|l|l|l|l|}
\cline { 2 - 7 } \multicolumn{1}{c|}{} & $\begin{array}{l}\text { Project } \\
\text { realization } \\
\text { cost }\end{array}$ & Year 1 & Year 2 & Year 3 & Year 4 & Year 5 \\
\hline Expenses & $15000 €$ & $12700 €$ & $11400 €$ & $13500 €$ & $12600 €$ & $13100 €$ \\
\hline Arrivals & $I$ & $12800 €$ & $15700 €$ & $17500 €$ & $19500 €$ & $20500 €$ \\
\hline Net cash & -15000 & 100 & 4300 & 4000 & 6900 & 7400 \\
\hline
\end{tabular}




\begin{tabular}{|l|l|l|l|l|l|l|}
\cline { 2 - 7 } \multicolumn{1}{c|}{} & $\begin{array}{l}\text { Project } \\
\text { realization } \\
\text { cost }\end{array}$ & Year 1 & Year 2 & Year 3 & Year 4 & Year 5 \\
\hline$(1+\mathrm{r}) \mathrm{n}$ & $/$ & 1.08 & 1.17 & 1.26 & 1.36 & 1.47 \\
\hline $\begin{array}{l}\text { Discounted } \\
\text { net cash }\end{array}$ & $/$ & 92.59 & 3686.56 & 3175.33 & 5071.71 & 5036.32 \\
\hline Net cash & -15000 & 100 & 4300 & 4000 & 6900 & 7400 \\
\hline $\begin{array}{l}\text { Cumulative } \\
\text { net cash }\end{array}$ & -15000 & -14900 & -10600 & -6600 & 300 & 7700 \\
\hline State & $<0$ & $<0$ & $<0$ & $<0$ & $>0$ & $>0$ \\
\hline
\end{tabular}

\section{Investment Indicators}

When deciding on one of several investments, i.e. when choosing one of several potential projects, it is not enough to consider only one parameter. If one attempts to analyze one of the essential parameters, one of the remaining ones will very soon come to light, which will point to some limitation, or to a more favorable variant of the project implementation.

The quantitative analysis is one of the basic elements in deciding to start the project, but also to analyze the justification of the choice of one of several offered projects (Gowthorpe, p.492). It is based on expected (estimated, planned) investments - expenditures, and estimated revenues in a given period.

The cost-benefit analysis of the project must take into account consideration of the following parameters:

- DR (Discount Rate)

- ROI (Return on Investment)

- IRR (Internal Rate of Return)

- NPV (Net Present Value)

- PbP (Payback Period)

\section{NPV- Net Present Value}

The net present value of money represents the discounted value of cash flows in each income period. Practically, the individual values of discounted cash flows would represent an amount that would, with an interest rate equal to the discount rate, give rise to the value of the cash flow. It would certainly be positive that the net present value (NPV) is higher than the value of the initial investment, which would show that we 
made profit, i.e. that the sum of the value of cash flows (PV-Present Value) reduced to today's value has a value higher than the initial investment. This would mean that on this day we would have more money than what we have invested in the development of a project.

$$
N P V=\frac{P V_{1}}{1+r}+\frac{P V_{2}}{(1+r)^{2}}+\frac{P V_{3}}{(1+r)^{3}}+\ldots+\frac{P V_{n}}{(1+r)^{n}}
$$

Each cash flow in a certain period is reduced by the n-th factor of the discount factor $(1+r)$, where $r$ is the discounted rate.

Table 4 - Discounted cash flow

Таблица 4 - Дисконтированное движение денежных средств Табела 4 - Дисконтовани новчани токови

\begin{tabular}{|l|l|l|l|l|l|l|}
\hline Net cash & -15000 & 100 & 4300 & 4000 & 6900 & 7400 \\
\hline$(1+r)^{\mathrm{n}}$ & $/$ & 1.08 & 1.17 & 1.26 & 1.36 & 1.47 \\
\hline $\begin{array}{l}\text { Discounted } \\
\text { Net cash }\end{array}$ & $/$ & 92.59 & 3686.56 & 3175.33 & 5071.71 & 5036.32 \\
\hline
\end{tabular}

Sum of discounted cash flows, combined with an initial investment, will give an indication of the net present value of the project. Since the sum of the discounted monetary values is 17062.5 , and the initial investment is 15000 , the net present value will be 2062.5.

The positive value of the net present value indicates that the project is cost-effective, i.e. that its interpretation would be the same as having additional $€ 2062.5$ at the start of the project launch.

\section{ROI- Return of Investment}

For a large number of projects, investors are in the first place interested in returning the investment, or in that sense, at the rate at which the capital invested will be returned. In other words, ROI is the rate at which the sum of the discounted values will be equal to the initial investment, i.e. when the total cash flow is equal to zero. Viewed through the planned costs and revenues, it represents the share of profit in the overall investment, i.e. the return of funds for one invested monetary unit. 


\begin{tabular}{|c|c|c|c|c|c|c|}
\hline \multicolumn{7}{|c|}{$\begin{array}{l}\text { Table 5 - Calculation of ROI } \\
\text { Tаблица } 5 \text { - Расчеm ROI } \\
\text { Tабела } 5 \text { - Прорачун ROI }\end{array}$} \\
\hline & $\begin{array}{l}\text { Project } \\
\text { realization } \\
\text { cost }\end{array}$ & Year 1 & Year 2 & Year 3 & Year 4 & Year 5 \\
\hline Expenses & $15000 €$ & $12700 €$ & $11400 €$ & $13500 €$ & $12600 €$ & $13100 €$ \\
\hline Incomes & I & $12800 €$ & $15700 €$ & $17500 €$ & $19500 €$ & $20500 €$ \\
\hline $\begin{array}{c}\text { Cumulative } \\
\text { expense }\end{array}$ & 15000 & 27700 & 39100 & 52600 & 65200 & 78300 \\
\hline $\begin{array}{l}\text { Cumulative } \\
\text { income }\end{array}$ & I & 12800 & 28500 & 46000 & 65500 & 86000 \\
\hline $\begin{array}{c}\text { Cumulative } \\
\text { net cash }\end{array}$ & -15000 & -14900 & -10600 & -6600 & 300 & 7700 \\
\hline ROI & $-100 \%$ & $-53.79 \%$ & $-27.11 \%$ & $-12.55 \%$ & $0.46 \%$ & $9.83 \%$ \\
\hline
\end{tabular}

\section{DR- Discount Rate}

In real business, the discount rate will represent the highest rate at which we can place certain funds. It can be practically determined as the highest interest rate that can be achieved on the market. In the analysis of the cost-effectiveness of the project, there is no direct significance for analyzing the financial effects of a particular project, but in decision making for the launch of the project, it plays a major role. If it is a unique project, which is not followed by another project, a very important information can be information on the amount of returns, i.e. about the rate at which resources are returned. The discount rate of $8 \%$ was taken as a case.

\section{IRR- Internal Rate of Return}

The internal rate of return on investment gives a realistic picture of the return on investment. It shows the rate at which the invested investment would bring profit during the observed period. It represents one of the important parameters when deciding and selecting an investment project. A definite prerequisite for accepting a project is that the IRR is higher than the discount rate, which would mean that the realization of the project will 
bring more profit over a certain period of time than simply investing in a bank or investment fund.

\section{PbP- PayBack Period}

A very important factor in deciding on one of several offered projects or investment programs is the time of return of the investment. The moment of return of the investment is the cutoff point of cumulative expenditures and cumulative revenues, i.e. the moment when the cumulative cash flow becomes positive, since at that moment cumulative revenues start exceeding cumulative expenditures.

\begin{tabular}{|c|c|c|c|c|c|c|}
\hline Net cash & -15000 & 100 & 4300 & 4000 & 6900 & 7400 \\
\hline $\begin{array}{c}\text { Cumulative } \\
\text { Net cash }\end{array}$ & -15000 & -14900 & -10600 & -6600 & 300 & 7700 \\
\hline State & $<0$ & $<0$ & $<0$ & $<0$ & $\geq 0$ & $>0$ \\
\hline
\end{tabular}

From the table, it is obvious that the return of the investment comes in the fourth year, so that a large part of the funds remains unsettled at the beginning of the fourth year, but still less than the planned income, and according to the projection of net cash should be compensated for a longer interval from the beginning of the fourth year.

Minus in the cumulative state should be compensated from the net cash that arises next year, so the very number of days will be obtained from the absolute ratio of the current negative state and the projected net cash next year. In the concrete case, that would be 6600/6900, or 0.956 . By conversion to time units, the data is 349 days, i.e. a total of 3 years and 349 days.

\section{Computer analysis}

Modern management requires the application of positive global practice, which shows the justification of decision-making based on realistic indicators and facts.

A program created in Microsoft Excel can be processed and analyzed for all data, which enables automatic data processing in real time, thus providing analyzes for the shortest time, solving and obtaining the results needed for decision making. 
The program gives the possibility to quickly, easily and efficiently obtain the results, i.e. data on parameters ROI, IRR, NPV and PbP.

\begin{tabular}{|c|c|c|c|c|c|c|}
\hline Project: XYZ & & & & & & \\
\hline Investments & Initial & Year 1 & Year 2 & Year 3 & Year 4 & Year 5 \\
\hline Equipment purchase & $600 €$ & & & $400 €$ & & \\
\hline Renting an object & $3000 €$ & $3000 €$ & $3000 €$ & $3000 €$ & $3000 €$ & $3000 €$ \\
\hline Certification & $1200 €$ & & & $1000 €$ & & \\
\hline Procurement of software & $4000 €$ & $2000 €$ & & & & \\
\hline Sallaries & $3000 €$ & $3500 €$ & $4000 €$ & $4500 €$ & $5000 €$ & $5500 €$ \\
\hline Travelling & $1200 €$ & $2000 €$ & $2200 €$ & $2400 €$ & $2400 €$ & $2400 €$ \\
\hline Ongoing costs & $2000 €$ & $2200 €$ & $2200 €$ & $2200 €$ & $2200 €$ & $2200 €$ \\
\hline
\end{tabular}

\begin{tabular}{|c|c|c|c|c|c|c|}
\hline Incomes & Initial & Year 1 & Year 2 & Year 3 & Year 4 & Year 5 \\
\hline Consulting & & $4000 €$ & $6000 €$ & $6000 €$ & $6000 €$ & $6000 €$ \\
\hline Software implementation & & $2000 €$ & $2500 €$ & $3000 €$ & $3500 €$ & $4000 €$ \\
\hline Business Education & & $4000 €$ & $4000 €$ & $5000 €$ & $6000 €$ & $6000 €$ \\
\hline Projects Realization & & $2800 €$ & $3200 €$ & $3500 €$ & $4000 €$ & $4500 €$ \\
\hline
\end{tabular}

\begin{tabular}{|l|l|}
\hline Discount Rate & $\mathbf{8} \%$ \\
\hline
\end{tabular}

Figure 2 - Input data

Puc. 2 - Входные данные

Слика 2 - Улазни подаци

The program created by the authors is designed to include only the values of the planned investments and revenues for each period, as well as the value of the discount rate. On the basis of data entered, the output gives the results obtained on the parameters necessary for decision making, as well as data on revenues, expenditures and cumulative cash flows by periods. 
Instead of making decisions based on intuitive analyses, or long, extensive and complicated calculations, using a computer quickly and easily results in the necessary results.

\begin{tabular}{|l|c|c|c|c|c|c|}
\hline \multicolumn{1}{|c|}{} & Initial & Year 1 & Year 2 & Year 3 & Year 4 & Year 5 \\
\hline Incomes & & $\mathbf{1 2 8 0 0}$ & $\mathbf{1 5 7 0 0}$ & $\mathbf{1 7 5 0 0}$ & $\mathbf{1 9 5 0 0}$ & $\mathbf{2 0 5 0 0}$ \\
\hline Investments & $\mathbf{1 5 0 0 0}$ & $\mathbf{1 2 7 0 0}$ & $\mathbf{1 1 4 0 0}$ & $\mathbf{1 3 5 0 0}$ & $\mathbf{1 2 6 0 0}$ & $\mathbf{1 3 1 0 0}$ \\
\hline Net cash & $\mathbf{- 1 5 0 0 0}$ & $\mathbf{1 0 0}$ & $\mathbf{4 3 0 0}$ & $\mathbf{4 0 0 0}$ & $\mathbf{6 9 0 0}$ & $\mathbf{7 4 0 0}$ \\
\cline { 2 - 8 } & Initial & Year 1 & Year 2 & Year 3 & Year 4 & Year 5 \\
\hline Cumulative incomes & & $\mathbf{1 2 8 0 0}$ & $\mathbf{2 8 5 0 0}$ & $\mathbf{4 6 0 0 0}$ & $\mathbf{6 5 5 0 0}$ & $\mathbf{8 6 0 0 0}$ \\
\hline Cumulative expenses & $\mathbf{1 5 0 0 0}$ & $\mathbf{2 7 7 0 0}$ & $\mathbf{3 9 1 0 0}$ & $\mathbf{5 2 6 0 0}$ & $\mathbf{6 5 2 0 0}$ & $\mathbf{7 8 3 0 0}$ \\
\hline Cumulative Net cash & $\mathbf{- 1 5 0 0 0}$ & $-\mathbf{1 4 9 0 0}$ & $\mathbf{- 1 0 6 0 0}$ & $\mathbf{- 6 6 0 0}$ & $\mathbf{3 0 0}$ & $\mathbf{7 7 0 0}$ \\
\hline
\end{tabular}

Figure 3-Analysis of incomes and outcomes

Рис. 3 - Анализ доходов и расходов

Слика 3 - Анализа прихода и расхода

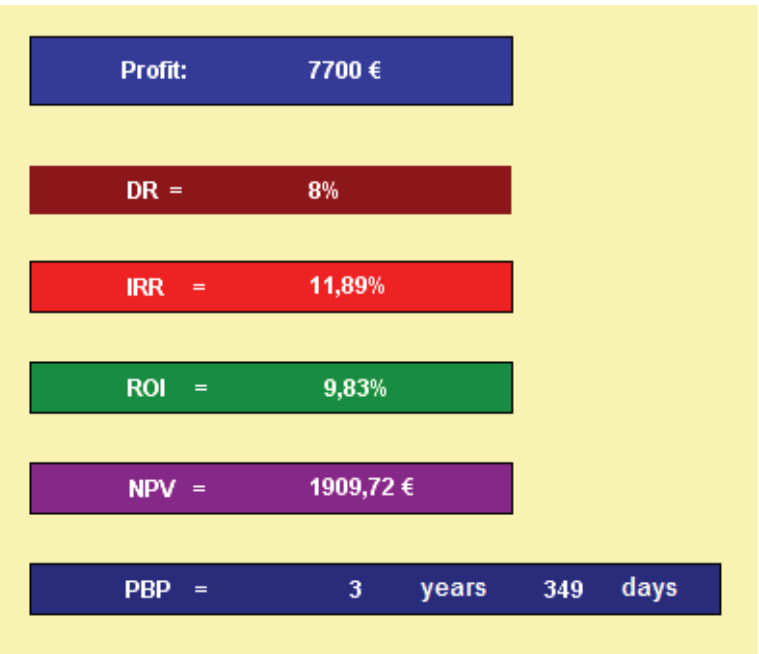

Figure 4-Analysis of the investment identifiers Puc. 4 - Анализ инвестиционных показателей Слика 4 - Анализа инвестиционих показатеља 


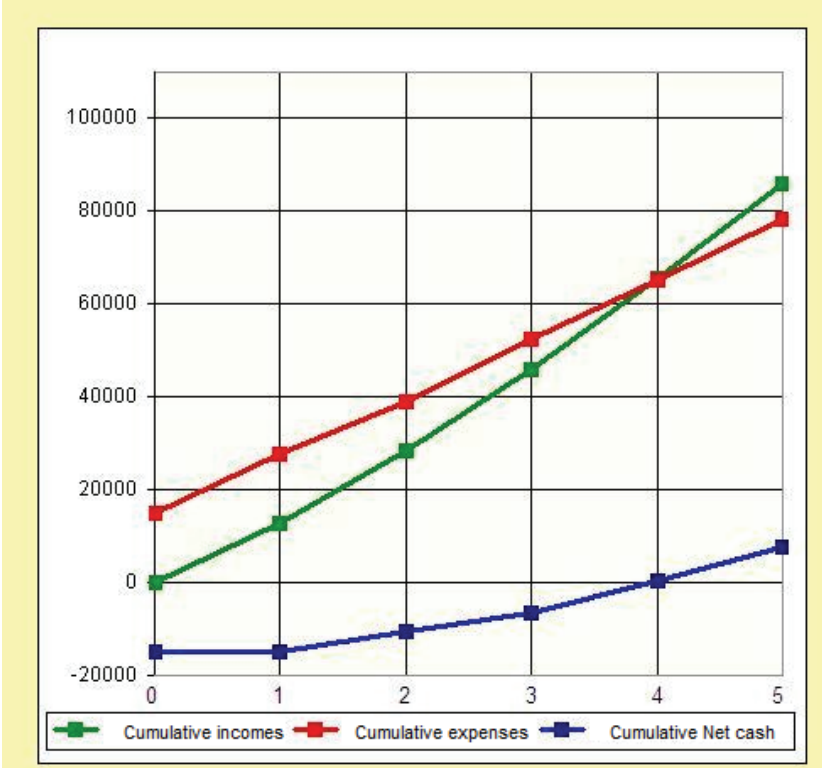

Figure 5 - Analysis of the investment identifiers

Puc. 5 - Анализ инвестиционных показателей

Слика 5 - Анализа инвестиционих показатеља

At the same time, the output provides consolidated data on significant parameters, as well as a graphic representation of the movement of revenues, expenditures and net cash, which contributes to a visual perception and presentation.

\section{Investment Decision Making}

The above mentioned indicators represent an important basis and relevant data that would help to make the optimal decision to enter the project, as well as the effects of the given project.

In particular, the data analysis also provides adequate data on cash flows, by periods and in total. Through this data, the current position can be determined, and at the portfolio level and effectively plan the allocation of resources - material, human and financial.

One piece of the initial information that is crucial for deciding on the choice of the project or the decision to initiate the project is the way the organization operates, i.e. the state of the organization in which the project team operates. 
The financial situation, in other words, the medium and long-term positions of the organization, directly and very significantly influence the nature of the project that will be accepted. Namely, organizations that have a very large budget, and stable long-term positions, can be defined for projects that do not have a quick return on investment, their key item is the amount of profit realized in the later stages of the exploitation of project results. For organizations with weaker positions, or developing organizations, an important element in deciding is the faster return of funds in order to provide liquidity and resources for regular functioning, commitments and investment in new projects. It is exactly the Payback Period that provides an image of the time needed to return the investment, or equalization of invested funds with realized income, viewed at a cumulative level (Keat \& Young, pp.324-330). In deciding on the choice of the project, the financial capacity of the organization that launches the project plays an important role, as well as the goals of the organization. For a given case, a period of 3 years and 349 days requires the provision of funds that would function until the full return of the investment and the transition to the net profit zone.

The next significant figure may be the rate at which the funds are invested. If it is a project whose results are exploited only by delivering the results of the project, or if the result of the project itself is a product that is delivered and which does not have any subsequent benefits, then in certain cases it is necessary to compare the discount rate with the internal rate of return on investments. For the value of the discount rate, the highest interest rate can be obtained in commercial banks, or the official discount rate determined by the official competent banking bodies.

When deciding on starting a project or choosing one of several projects, an internal rate of return (IRR) with a discount rate is often made, so the project is initiated if the internal rate of return is higher than the discount rate. This will mean that the investment brings more revenue through the project, than it would be achieved through pure investment through the banking sector, i.e. the investment is more cost-effective in this way. In the given case, the internal rate of return of $11.89 \%$ is higher than the discount rate of $8 \%$, which shows that a higher return would be achieved than the investment in the financial sector could make it.

One of the parameters in the investment analysis is the return on investment (ROI). A higher ROI means a higher return on investment, so it is logical to always choose a project that has a higher ROI, if the other parameters are the same. In the given case, the ROI of $9.83 \%$ shows that for every 100 money units invested, a profit of 9.83 cash units is realized. 


\section{Conclusion}

An important item in modern management is fact-based decisionmaking. Such an approach has full validation in the analysis of the costeffectiveness of the project, because of the exceptional significance of such analysis and results.

The starting point in each project is the cost-effectiveness of the project, which is perceived through the parameters NPV, ROI, IRR and $\mathrm{PbP}$. In order to get a realistic view of the project, it is necessary to look at each of the parameters and make conclusions based on the analysis.

There is no unique model of decision-making based on given parameters, because each project is unique, so it is realized in a different way and depends on different conditions and parameters.

When analyzing, the nature and purpose of the project, the market conditions, the available resources and the liquidity of the organization, as well as the importance of returning investments in a given period, should be taken into account. Each of the items will have a different impact on the execution of the project, and therefore the importance in the analysis and decision-making.

By looking at the above parameters, one can definitely conclude that a project is more valuable when it has a higher net present value (NPV), a return on investment (ROI) and an internal rate of return (IRR), or a shorter investment return time $(\mathrm{PbP})$.

However, as in real terms it is difficult to achieve optimal results for all parameters, if there is a choice between two or more projects, certain compromise on one of the parameters will definitely have to be made.

When choosing one of possible, offered or available projects, all options should be considered at the portfolio manager level, including more complex analyses of operational and financial risks, without relying on only one analysis. Portfolio managers in the given situation must count on adequate diversification, so as not to jeopardize company's / organization's positions, as well as on the likelihood of achieving the results of the project, or on a possible impact of project failure on total business.

Each project is also a unique, special business venture that gives certain economic parameters in given conditions and with given market conditions; therefore, at the portfolio level, each project has to be approached individually in detail, on the basis of real and relevant parameters in order to make an optimal decision. 


\section{References}

Barkley, B. \& Saylor, J., 2001. Customer Driven Project Management: Building Quality into Project Processes. McGraw Hill.

DeCarlo, D., 2004. Extreme Project Management. San Francisco: JosseyBass Willey Imprint.

Đedović, B., 2010. Vođenje i vrednovanje projekata. Belgrade: Fakultet za menadžment malih i srednjih preduzeća (in Serbian).

Gitman, L., 2006. Essentials of Managerial Economics. Boston: Pearson Addison Wesley.

Gowthorpe, C., 2005. Business Accounting and Finance. London: Thomson Learning.

Keat, P. \& Young, P., 2006. Managerial Economics. New Jersey: Pearson Prentice Hall.

Khoury, S., 2014. Managing Project Cost, Revenue and Profit. Available at: http://www.pdhonline.org/courses/p132/p132.htm. Accessed: 2014 Jun 22.

-Project Management Institute, PMI. 2013. Project Management Body of Knowledge, 5th ed. Pennsylvania.

АНАЛИЗ ОКУПАЕМОСТИ ИНВЕСТИЦИОННОГО ПРОЕКТА

Александар Ж. Дреновац ${ }^{\text {, }}$ Братислав Ж. Дреновац

а Дренус, г. Белград, Республика Сербия

б Вооруженные силы Республики Сербия, Центр обучения и развития, Учебный центр, г. Белград, Республика Сербия

ОБЛАСТЬ: проектный менеджмент, портфельный менеджмент, инвестиционный анализ

ВИД СТАТЬИ: профессиональная статья

ЯЗЫК СТАТЬИ: английский

Резюме:

Решение о разработке и осуществлении проекта должно быть основано на измеряемых параметрах. Следовательно, выбор проектов на портфельном уровне делается на основании анализа параметров NPV, ROI, IRR и PbP. Ответственные лица обязаны владеть информацией и знаниями о характеристиках и взаимосвязи между данными параметрами, так как это является важным фрактором успеха в организации и управлении инвестициями.

Ключевые слова: управление проектами, бюджет проекта, инвестиционный анализ. 


\section{АНАЛИЗА ИСПЛАТИВОСТИ ПРОЈЕКТА}

Александар Ж. Дреновац ${ }^{\mathrm{a}}$, Братислав Ж. Дреновац

а Дренус, Београд, Република Србија

б Војска Србије, Центар за обуку и усавршавање, Команда за обуку, Београд, Република Србија

ОБЛАСТ: пројектни менаџмент, портфолио менаџмент, инвестициона анализа

ВРСТА ЧЛАНКА: стручни чланак ЈЕЗИК ЧЛАНКА: енглески

\section{Сажетак:}

Одлука о покретању и реализацији пројекта мора бити заснована на мерљивим показатељима. Зато се избор пројекта на портфолио нивоу заснива на анализи параметара НПВ, РОИ, ИРР и ПбП. Доносиоци одлука морају познавати карактеристике и везе датих параметара и, на основу њихове значајности за организацију, адекватно управљати инвестицијама.

Кључне речи: управљање пројектима, бучет пројекта, анализа инвестиција.

Paper received on / Дата получения работы / Датум пријема чланка: 26.06.2014. Manuscript corrections submitted on / Дата получения исправленной версии работы / Датум достављања исправки рукописа: 09.11.2017.

Paper accepted for publishing on / Дата окончательного согласования работы / Датум коначног прихватања чланка за објављивање: 11.11.2017.

(c) 2018 The Authors. Published by Vojnotehnički glasnik / Military Technical Courier (www.vtg.mod.gov.rs, втг.мо.упр.срб). This article is an open access article distributed under the terms and conditions of the Creative Commons Attribution license (http://creativecommons.org/licenses/by/3.0/rs/).

() 2018 Авторы. Опубликовано в «Военно-технический вестник / Vojnotehnički glasnik / Military Technical Courier» (www.vtg.mod.gov.rs, втг.мо.упр.срб). Данная статья в открытом доступе и распространяется в соответствии с лицензией «Creative Commons» (http://creativecommons.org/licenses/by/3.0/rs/)

(C) 2018 Аутори. Објавио Војнотехнички гласник / Vojnotehnički glasnik / Military Technical Courier (www.vtg.mod.gov.rs, втг.мо.упр.срб). Ово је чланак отвореног приступа и дистрибуира се у складу са Creative Commons licencom (http://creativecommons.org/licenses/by/3.0/rs/). 